logos_i_ethos_2016_(40)_numer_specjalny_1, s. 163-175

DOI: http://dx.doi.org/10.15633/lie.1706

Agnieszka Janas

Uniwersytet Papieski Jana Pawła II w Krakowie

\title{
Szczęście społeczeństwa nowego kapitalizmu według Richarda Sennetta
}

Filozofowie i socjologowie w różny sposób interpretują i opisują stan współczesnego społeczeństwa za pomocą odwołania się do jednej, szczególnie charakterystycznej jego cechy. Społeczeństwo konsumentów to jedna z postaci społeczeństwa ponowoczesnego, która bardzo często jest

Agnieszka Janas, mgr, doktorantka w Katedrze Filozofii Społecznej i Polityki na Wydziale Filozoficznym Uniwersytetu Papieskiego Jana Pawła II w Krakowie, absolwentka filologii polskiej i oligofrenopedagogiki Uniwersytetu Pedagogicznego im. Komisji Edukacji Narodowej w Krakowie. Zainteresowania naukowe: filozofia społeczna, etyka, filozofia języka i filozofia kultury. przedmiotem badań. Zygmunt Bauman tak je opisuje: „Społeczeństwo konsumentów to takie społeczeństwo, które promuje wybór konsumpcyjnego stylu życia i strategii życiowych, zachęca do niego lub przymusza, pogrążając w niełasce wszelkie jego kulturowe alternatywy" ". Współczesne społeczeństwa krajów wysoko rozwiniętych charakteryzują się konsumpcyjnym stylem życia, co nie pozostaje bez wpływu na sferę moralności, ujmującej to, co społecznie uznawane za godne lub niegodne pożądania w odniesieniu do drugiego człowieka. Za trafną charakterystykę tego szczególnego typu społeczeństwa może posłużyć rozmowa, którą przeprowadziłam z pewnym starszym panem z okazji obchodzonej przez niego i żonę pięćdziesiątej rocznicy ślubu. $\mathrm{Na}$ pytanie, jak udało im się razem przeżyć tyle lat, odpowiedział: „Oboje z żoną należymy do pokolenia, które gdy się coś zepsuło, to starało się to naprawić. Dzisiaj się już tego nie robi”. 
Richard Sennett, amerykański filozof i badacz kultury, określa współczesne społeczeństwo mianem społeczeństwa nowego kapitalizmu ${ }^{2}$. Jedną z jego charakterystycznych cech jest ujmowanie człowieka jako przede wszystkim konsumenta, któremu sprzedać można wszystko: nie tylko produkty, lecz także osoby (np. polityków, gwiazdy) oraz idee i wartości - sukces, zdrowie czy piękno. Kapitalizm, wolny rynek i wolność wyboru doprowadziły do sytuacji, w której konsumpcja jest już nie tylko prawem, przywilejem, lecz stała się, według Sennetta, przymusem i nałogiem, w którego władzy pozostaje konsument ${ }^{3}$.

Sennett wskazuje na zmiany w organizacji systemu kapitalistycznego, które rozpoczęły się w ostatnich dwudziestu latach ubiegłego wieku, i opisuje ich wpływ na społeczeństwo, które ze względu na te zmiany nazywa społeczeństwem nowego kapitalizmu. Używany do dookreślenia kapitalizmu przymiotnik „nowy” stosowany jest do opisu współczesnego społeczeństwa nie tylko przez Sennetta. Według Jeana Baudrillarda "nowość" jest jednym z bardzo ważnych wyznaczników, zasad świata konsumpcji ${ }^{4}$. Zmiany, o których pisze Sennett, dotyczą przede wszystkim dużych firm zatrudniających kilka tysięcy osób, co wpływa na całe społeczeństwo.

Jedną $\mathrm{z}$ tych istotnych zmian jest przejście od władzy menedżerów bezpośrednio zarząadzających przedsiębiorstwem do władzy udziałowców, niezwiązanych z przedsiębiorstwem, a jedynie czerpiących zyski z posiadanych akcji. Dzięki temu na wniosek akcjonariuszy jest możliwe inwestowanie kapitału zgromadzonego na koncie firmy jako zabezpieczenia i lokowania go w innych inwestycjach ${ }^{5}$. Zmiana ta możliwa była dzięki rozwojowi instytucji finansowych i bankowych, który z kolei umożliwił dokonywanie fuzji i przejęć jednych firm przez inne, a to pozwalało inwestorom zakładać i niszczyć korporacje, podczas gdy pracujący w nich

\footnotetext{
szawa 2010.

2 Por. R. Sennett, Kultura nowego kapitalizmu, tłum. G. Brzozowski, K. Osłowski, War-

3 Zob. R. Sennett, Kultura nowego kapitalizmu, dz. cyt., s. 109.

4 Por. J. Baudrillard, Społeczeństwo konsumpcyjne. Jego mity i struktury, tłum. S. Królak, Warszawa 2006.

$5 \quad$ R. Sennett, Kultura nowego kapitalizmu, dz. cyt., s. 32.
} 
menedżerowie nie mieli na to żadnego wpływu, a często nawet o tym nie wiedzieli ${ }^{6}$.

Za najważniejszą zmianę, która wpłynęła zasadniczo na rozwój społeczeństwa nowego kapitalizmu, należy - zdaniem Sennetta - uznać rozwój technologii komunikacyjnych, szczególnie Internetu, który umożliwia przepływ informacji w sposób natychmiastowy, a jednocześnie skraca dystans między ludźmi. Sieć to źródło informacji, bieżących wiadomości o wydarzeniach na świecie, ale też w sieci można znaleźć wiele dokumentów, od tych ważnych, umieszczanych na stronach instytucji rządowych oraz publicznych, po różnego rodzaju dokumenty i programy zamieszczanych przez osoby prywatne; od programów informacyjnych, przez rozrywkowe, po gry komputerowe. Sieć jest wykorzystywana również do zakupów. Obecnie strony internetowe zadziwiają bogactwem grafiki i zdjęciami o wysokich walorach artystycznych ${ }^{7}$.

Te trzy zmiany odegrały zasadniczą rolę w procesie globalizacji, ponieważ zniosły granice geograficzne, etniczne i kulturowe między ludźmi. Społeczeństwo nowego kapitalizmu jest przede wszystkim efektem szybkiego rozwoju cywilizacji i nowych technologii, która rozwija się w otoczeniu demokracji wolnorynkowej i zasad demokratycznego państwa ${ }^{8}$. Na pewno nie bez znaczenia dla tych procesów był upadek komunizmu i otwarcie nowych, atrakcyjnych rynków zbytu w Europie Środkowo-Wschodniej, co umożliwiło ekspansję wielkich firm na rynki dotychczas dla nich niedostępne. Wielkim korporacjom te potężne rynki zbytu dały możliwość zaoferowania swoich towarów i usług wielu milionom potencjalnych nabywców, a tym samym umożliwiły dalszy rozwój.

Innym skutkiem procesu globalizacji są zmiany w wielu pozarynkowych instytucjach, szczególnie państwa opiekuńczego, takich jak służba zdrowia, system emerytalny oraz edukacyjny ${ }^{9}$. Wydaje się, że globali-

6 Tzw. wrogie przejęcia w celu likwidacji firmy, zob. R. Sennett, Kultura nowego kapitalizmu, dz. cyt., s. 33 .

7 S. Morreale, B. Spitzberg, J. Barge, Komunikacja między ludźmi. Motywacja, wiedza i umiejętności, tłum. P. Izdebski, A. Jaworska, D. Kobylińska, Warszawa 2007, s. 204.

8 S. Morreale, B. Spitzberg, J. Barge, Komunikacja między ludźmi, dz. cyt., s. 9.

9 S. Morreale, B. Spitzberg, J. Barge, Komunikacja między ludźmi, dz. cyt., s. 10. 
zacja doprowadziła do tego, iż wszyscy stali się równi wobec zagrożeń związanych np. z terroryzmem, bez względu na miejsce zamieszkania, dochody czy wykształcenie. W efekcie pojawia się poczucie niepewności, które pociąga za sobą strach przed potencjalnymi zagrożeniami. Zarówno strach, jak i niepewność konsument likwiduje przy pomocy konsumpcji. Poczucie kruchości i ulotności życia powoduje, iż na nowo odżywa słynna sentencja Carpe diem!, stając się motorem i jednocześnie usprawiedliwieniem podejmowanych działań i praktyk. Społeczeństwo nowego kapitalizmu czerpie swoje szczęście $z$ hedonizmu; jedną z głównych zasad staje się zasada przyjemności. Egoizm i hedonistyczne nastawienie powodują pojawienie się nastroju wszechobecnego „karnawału”, nie pozostawiając miejsca oraz czasu na altruizm i refleksję. Rynek, jak się wydaje, wyzbył się wszelkich ograniczeń: czasowych, moralnych i przestrzennych, i stał się w niemal absolutny sposób wolny, a przy tym wszystko zyskało swoją cenę ${ }^{10}$.

Takie przemodelowanie współczesnych ludzi powoduje, że odczuwają oni przymus kupowania. Sennett wprost twierdzi, że współczesny konsument jest uzależniony od kupowania, które staje się jego namiętnością i wręcz nałogiem ${ }^{11}$. Media, reklama, nauka, technologia i medycyna oferują osiągnięcie szczęścia, sukcesu i społecznego poważania pod warunkiem zakupu produktu, usługi czy zabiegu z zakresu medycyny estetycznej. W efekcie tożsamość człowieka jest konstruowana w oparciu o konsumpcję. Ciągłe wypróbowywanie nowych obrazów własnego „ja” powoduje niestabilność naszych relacji z otoczeniem.

W społeczeństwie nowego kapitalizmu łatwo można budować tożsamości równoległe - wystarczy skorzystać z dwóch lub więcej gotowych, oferowanych na rynku przez kompetentne firmy, projektów. Przez pierwszą połowę dnia możemy być przykładnym pracownikiem wielkiej firmy, pracującym na odpowiedzialnym, kierowniczym stanowisku, a potem - stać się ubranym w czarną skórzaną kurtkę i jeżdżącym

10 Odnośnie do ograniczeń rynku zob. M. Sandel, Czego nie można kupić za pieniądze. Moralne granice rynku, tłum. A. Chromik, T. Sikora, Warszawa 2013.

11 R. Sennett, Kultura nowego kapitalizmu, dz. cyt., s. 109n. 
szybkim motocyklem piratem drogowym. Mimo braku trwałości takich projektów tożsamościowych postrzegane są one przez konsumentów jako atrakcyjne.

Jednak dążenie do szczęścia nie jest dostępne w jednakowym stopniu wszystkim członkom współczesnego społeczeństwa. Dzisiejszy hedonizm to nie tylko nabywanie tradycyjnych dóbr materialnych, ale także nabywanie wartości, które im towarzyszą. Poziom satysfakcji i szczęścia jest wyznaczany przez pozycję materialną. Ponieważ nie każdy może osiągnąć pożądany poziom konsumpcji, a tym samym satysfakcji, oferuje się ludziom kredyty, pożyczki i inne formy nabywania dóbr i usług potrzebnych do szczęścia ${ }^{12}$.

Wartość dla współczesnego człowieka to pojęcie względne. Coraz częściej utożsamia się je z rzeczami, ma ono znaczenie wyłącznie w wymiarze materialistycznym. Joanna Mysona Byrska pisze: „Człowiek, który stał się konsumentem, żyje w świecie o horyzoncie aksjologicznym ograniczonym do wartości materialnych i utylitarnych. Życie w świecie konsumpcji jest skoncentrowane na centrum handlowym, gdzie znajduje się wiele towarów"13. Dobra materialne są tak popularne, ponieważ dostępne są niemal natychmiast, a od chwili upowszechnienia Internetu możliwe również do nabycia bez najmniejszego wysiłku i zwykle dzięki kilku kliknięciom. Szybkie zakupy w sklepie internetowym, zrealizowane również w czasie pracy, nie są dzisiaj żadnym problemem ${ }^{14}$, a znacznie poszerzają konsumpcyjne możliwości pracującego na swoją konsumpcję konsumenta.

Wszystko to sprawia, że społeczeństwo coraz chętniej oddaje się konsumpcji, która zdominowała postmodernistyczną wizję świata i obowiązujące na rynku mechanizmy. Konsumpcjonizm nie tylko daje człowieko-

12 G. Ritzer, Magiczny świat konsumpcji, tłum. L. Stawowy, Warszawa 2012, s. 254-255.

13 J. Mysona Byrska, Nove hodnoty v magickom svete konzumpcie, [w:] Fyzika a etika VIII. Veda ako kulturny fenomen, red. I. Mihalikova, Nitra 2013, s. 283: „Človek, ktorý sa stal spotrebitelom, žije vo svete s axiologickým horizontom zúženým na materiálne a utilitárne hodnoty. Najdôležitejšie hodnoty sú materialistické hodnoty a finančné prostriedky. Život vo svete spotreby je sústredený v nákupnom centre, kde je vela spotrebného tovaru" (tłum. A. J.).

14 Por. G. Ritzer, Magiczny świat konsumpcji, dz. cyt., s. 251-253. 
wi satysfakcję, poczucie wyższości i prestiżu, ale także stwarza wrażenie wolności oraz pozwala na dokładne określenie pozycji konsumenta w danej społeczności. Kupując przedmioty, nabywa się nie tylko wartość użytkową, ale również symboliczną, którą można dowolnie przeżywać, kontemplować i odczuwać ${ }^{15}$.

Ludzie uciekają w konsumpcjonizm lub tak często podlegają jego wpływom głównie dlatego, że każda jednostka podświadomie dąży do zapewnienia sobie szczęśliwego życia, co dzięki konsumpcji wydaje się osiągalne i relatywnie proste. Wystarczy coś kupić i już człowiek jest szczęśliwy. Konsumpcja daje możliwość eksploatacji nowych aspektów i szans, jakie stwarza rozwój życia zawodowego i stawianie na karierę. Bowiem to dzięki pieniądzom można zrealizować swoje marzenia, zaspokoić większość potrzeb oraz poprawić pozycję społeczną, a co za tym idzie - osiągnąć szczęście. Sennett uważa, że aby odnieść sukces zawodowy, należy posiadać umiejętność zrzucania odpowiedzialności na innych i przypisywania sobie osiągnięć niekoniecznie własnych ${ }^{16}$. Dzięki temu mimo braku zaangażowania konsument będzie poważany przez innych i osiągnie swój sukces na miarę świata konsumpcji dużo szybciej.

W społeczeństwie nowego kapitalizmu dochodzi również do zaniku podstawowych relacji społecznych, które powinny zachodzić na linii człowiek-człowiek. Dzieje się tak głównie dlatego, że społeczeństwo skupione na ciągłym pozyskiwaniu dóbr materialnych automatycznie nastawia się na ich zdobywanie i tylko przedmioty materialne ma w zasięgu swojej uwagi. Pozostałe elementy, w tym przede wszystkim inni ludzie, schodzą na dalszy plan, ponieważ przedmioty stanowią ich doskonały substytut i zapewniają szczęście i pozycję społeczną, co na chwilę obecną jest dla człowieka najważniejsze i najbardziej pożądane ${ }^{17}$.

W tym miejscu warto przytoczyć fragment z utworu Antoine’a de Saint-Exupéry’ego Mały Książę: „Ludzie mają zbyt mało czasu, aby co-

15 J. Baudrillard, Społeczeństwo konsumpcyjne..., dz. cyt., s. 18-19.

16 R. Sennett, Korozja charakteru..., dz. cyt., s. 102-103.

17 Według Jeana Baudrillarda człowiek otacza się przedmiotami i one mu towarzyszą obecnie częściej niż ludzie. J. Baudrillard, Społeczeństwo konsumpcyjne..., dz. cyt., s. 21. 
kolwiek poznać. Kupują w sklepach rzeczy gotowe. A ponieważ nie ma magazynów z przyjaciółmi, więc ludzie nie mają przyjaciół"18. To, co pisze Saint-Exupéry, jest bardzo charakterystyczne dla społeczeństwa konsumpcyjnego. Atomizacja, osłabienie więzi międzyludzkich, zanik solidarności i wspólnotowości powodują, że jednostka traci poczucie zależności od otaczających ją osób. Współczesne społeczeństwo stworzyło specyficzny typ człowieka, którego cechuje aspołeczność i brak zaangażowania w życie społeczne. Sennett nazywa ten typ człowieka niekooperacyjnym „ja" ${ }^{\prime 19}$. Osoba taka w życiu społecznym nosi maskę, nie okazując innym swoich myśli i uczuć. Otacza się przedmiotami, a nie ludźmi. Jest przeświadczona, że sama stanowi o swoim losie, sama jest w stanie zadbać o siebie i nic nikomu nie zawdzięcza. To wszystko sprawia, że łatwo podejmuje decyzje i działania o charakterze egoistycznym.

Społeczeństwo nowego kapitalizmu swoim zachowaniem i sposobem działania z czasem wykluczyło z kanonu wartości szacunek, pozbawiając się tym samym możliwości refleksji nad życiem i jego moralnymi aspektami. Życie jednostki jest przepełnione koniecznością podejmowania nieustannych wyborów, ale najważniejszym kryterium tych wyborów i celem jednostki staje się przede wszystkim konsumpcja i wszystko, co się z nią wiąże, a pozostałe kwestie odsuwane są na dalszy plan.

W dawnym społeczeństwie źródłem szczęścia była przede wszystkim praca, która pozwalała jednostce czerpać satysfakcję, mieć szacunek do siebie i wzbudzać ten szacunek $\mathrm{u}$ innych. Istotą tego systemu był czas: uporządkowany, pozwalający na długoterminowe planowanie, a przede wszystkim przewidywalność i stabilność ${ }^{20}$. Współcześnie mamy do czynienia ze zjawiskiem odrzucenia wartości przypisywanych kiedyś solidności i stabilności i zastąpienia ich tymczasowością oraz nietrwałością ${ }^{21}$.

\footnotetext{
18 A. de Saint-Exupéry, Mały Książe, tłum. J. Szwykowski, Warszawa1985, s. 62.

19 R. Sennett, Razem. Rytuały, zalety i zasady współpracy, tłum. J. Dzierzgowski, Warszawa 2013, s. 235.

${ }_{20}$ M. Weber, Etyka protestancka a duch kapitalizmu, tłum. B. Baran, P. Miziński, Warszawa 2010 , s. $49-50$.

21 Z. Bauman, Konsumowanie życia, dz. cyt., s. 94.
} 
Społeczeństwo nowego kapitalizmu nie odczuwa dumy z pracy, gdyż we współczesnym świecie korporacji solidna i fachowa praca utraciła swój moralny prestiż i została zastąpiona przez McPracę, która nie tylko nie dostarcza wykonującemu ją satysfakcji, ale jest nisko ceniona przez społeczeństwo i mało płatna ${ }^{22}$. To głównie w przestrzeni tych prac uległ zmianie moralny prestiż jednostki wynikający ze stabilności wykonywanej $\operatorname{pracy}^{23}$. Utrata szacunku do fachowej pracy we współczesnych społeczeństwach krajów uprzemysłowionych wywołała kryzys podstawowych wartości, a kryzys etyki protestanckiej stał się przyczyną powstawania nierówności społecznych, ponieważ z pola widzenia zniknęły najważniejsze elementy tej etyki: długoterminowe myślenie w kategoriach społecznych oraz umiejętność cierpliwego czekania na zysk ${ }^{24}$.

To zapewniało wielu ludziom poczucie własnej wartości, a co za tym idzie - było dla nich źródłem szczęścia. Nie zaawansowane technologie, szybkie przesyłanie danych, globalne rynki finansowe czy wolny handel, lecz właśnie aspekt czasowy nowego kapitalizmu ma najbardziej bezpośredni wpływ na nasze życie prywatne i wiąże się z niepewnością i rozpaczliwymi próbami osiągnięcia szczęścia poprzez ciągłe nabywanie przedmiotów. Funkcjonowanie społeczeństwa nowego kapitalizmu nie oznacza, że obok konsumentów w ogóle nie ma producentów, a normy zmieniającej się ciągle mody zastąpiły trwałe normy wypływające z obyczaju, zaś tradycyjny etos pracy, oparty na obowiązkowości i stabilizacji, zanikł całkowicie, ustępując miejsca hedonizmowi. Obecnie społeczeństwo producentów miesza się ze społeczeństwem konsumentów, zachowania ludzi reguluje zarówno moda, jak i obyczaj. Praca zawodowa jest cały czas centralnym wymiarem naszej codzienności, przesunęły się jednak akcenty charakterystyczne dla codzienności ludzkiego życia. Zygmunt Bauman pisze: „Powodem, dla którego owo nowoczesne społeczeństwo starszego typu nazywano «społeczeństwem produkcyjnym», był fakt, że angażowało ono swoich członków przede wszystkim jako producentów;

\footnotetext{
22 R. Sennett, Kultura nowego kapitalizmu, dz. cyt., s. 61.

23 R. Sennett, Kultura nowego kapitalizmu, dz. cyt., s. $61 \mathrm{n}$.

24 R. Sennett, Kultura nowego kapitalizmu, dz. cyt., s. 65-66.
} 
sposób, w jaki ich kształtowało, był podyktowany potrzebą grania tej roli, a normą, którą społeczeństwo to narzucało swoim członkom, była umiejętność i chęć odegrania owej roli. Na obecnym etapie rozwoju - w okresie zwanym «drugą fazą nowoczesności», «późną nowoczesnością» czy też «ponowoczesnością» - społeczeństwo angażuje swoich członków - znowu przede wszystkim - w funkcji konsumentów. Sposób, w jaki dzisiejsze społeczeństwo kształtuje swoich członków, jest podyktowany głównie potrzebą grania roli konsumenta, a normą, jaką społeczeństwo narzuca swoim członkom, jest umiejętność jej odegrania"25. Zdaniem Baumana człowiek sprowadzony jest w społeczeństwie konsumpcyjnym do roli pionka, którego zadaniem jest konsumowanie, zużywanie i wyrzucanie zużytych dóbr. Sennett zwraca uwagę na konieczność nawiązywania współpracy z innymi ludźmi i aktywnego angażowania się $\mathrm{w}$ działania na rzecz lokalnych wspólnot. Bierna obecność, czyli formalna przynależność do jakiejś organizacji bez aktywnego działania w niej, tak współcześnie popularna szczególnie w Stanach Zjednoczonych, jest charakterystyczna dla konsumenta ${ }^{26}$. Przynależy on, bo tak wypada, ale nic $z$ tego nie wynika, nie zabiera mu to czasu na konsumpcję i zajmowanie się tylko i wyłącznie własnymi sprawami. Bierne uczestnictwo to charakterystyczne postawa konsumenta. Widoczne jest to również w prowadzonych rozmowach, które jednak prawdziwymi rozmowami nie są. Mysona Byrska w tym kontekście pisze: „Konsumenci rozmawiają o konsumpcji i kupowanych dobrach, jest to rozmowa łatwa, nie wymagająca większego wysiłku intelektualnego, ani specjalnej erudycji, no może poza znajomością asortymentu sklepów i aktualnych ofert. Taka prosta rozmowa skupiona na przedmiotach materialnych daje poczucie bycia członkiem wspólnoty konsumującej i jest dla większości konsumentów skupionych na dobrach materialnych zupełnie wystarczająca dla zaspokojenia potrzeb innych niż głód i pragnienie, których jednak nie nazwano by potrzebami wyższymi”27.

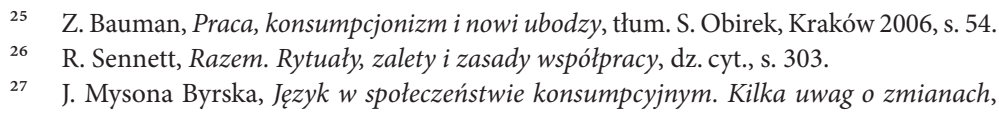
[w:] Język - podmiot - rzeczywistość. Szkice na temat języka i mowy oraz ich roli $w$ życiu indywidualnym i zbiorowym, red. M. Żardecka-Nowak, J. Skrzypek-Faluszczak, Rzeszów 2015, s. 171. 
Współczesny kapitalizm i jego sposób funkcjonowania spowodowały, że w ludziach obudziło się pragnienie wspólnoty, a jej tworzenie stało się dla wielu poszukiwaniem szczęścia $\mathrm{w}$ innych sferach życia, niezwiązanych z konsumpcją ${ }^{28}$. W ostatnim czasie coraz bardziej popularne są antyglobalizacyjne ruchy społeczne, których celem jest tworzenie w swoim otoczeniu przestrzeni publicznej wolnej od konsumpcji i marketingu. Dużą rolę w działaniu tych antyglobalizacyjnych ruchów odgrywają nowe technologie komunikacyjne, które dostarczają wiadomości "tu i teraz”, umożliwiając ludziom podjęcie realnych działann ${ }^{29}$.

Czy życie we wspólnocie może dać człowiekowi szczęście? Wspólne przekonania, obyczaje i wartości na pewno mogą pomóc jednostce w budowaniu poczucia własnej tożsamości, ale wspólnota nie jest w stanie wypełnić całego życia jednostce i zapewnić jej szczęścia. Być może rację miał Zygmunt Freud, który twierdził, że człowiekowi do szczęścia potrzebne są dwie rzeczy: Liebe und Arbeit - miłość i praca ${ }^{30}$. Ludzie wydają się nie dostrzegać problemów płynących z kryzysu wartości niematerialnych, bez których szczęście człowieka nie jest możliwe, takich jak: rodzina, empatia oraz trwałe relacje międzyludzkie oparte na tolerancji i szacunku.

Sennett wskazuje jako rozwiązanie problemów zmniejszanie nierówności w społeczeństwie nowego kapitalizmu, która przebiega na linii możliwości finansowych poszczególnych członków społeczeństwa, z których większość balansuje na krawędzi ubóstwa, podczas gdy nieliczna grupa konsumuje w nadmiarze. Społeczeństwo nowego kapitalizmu jest społeczeństwem niesprawiedliwym nie tylko dlatego, że nie zapewnia swoim członkom równej redystrybucji dóbr, ale również dlatego, że oszukuje biednych członków społeczeństwa, roztaczając przed nimi wizję lepszego świata, do którego ma ich zaprowadzić konsumpcyjny model życia, na jaki raczej nie mają szansy mimo podejmowanych wysiłków.

Omawiając cechy społeczeństwa nowego kapitalizmu i jego dążenie do szczęścia, nie sposób pominąć nowych zjawisk, takich jak ekologizacja 
konsumpcji i dekonsumpcja ${ }^{31}$. Ekologizacja sprzeciwia się modelowi funkcjonującemu w świecie nowego kapitalizmu, opartemu na krótkotrwałej korzyści, bez analizowania skutków postępowania konsumenckiego jednostki i społeczeństwa dla środowiska naturalnego i warunków życia przyszłych pokoleń. Ekologizacja uświadamia wpływ działań konsumenckich na środowisko naturalne, a podporządkowanie konsumpcji ochronie środowiska poprawia jakość życia i sprzyja zdrowiu konsumentów. Dekonsumpcja polega na świadomej rezygnacji z konsumpcji, na ograniczaniu jej do faktycznych potrzeb jednostki, wynikających z jej indywidualnych wymagań, oraz sprowadzenie konsumpcji do roli instrumentu, którego rolą jest ułatwianie życia ${ }^{32}$. Nie bez znaczenia dla rozwoju tego nurtu był światowy kryzys finansowy trwający od 2007 roku. Na fali kryzysu pojawił się typ konsumenta świadomego skutków swoich zachowań i dążącego do osiągnięcia życiowej równowagi i prostoty ${ }^{33}$.

Na szczęście nie jesteśmy bezbronni wobec konsumpcji. Dysponujemy narzędziami, których umiejętne wykorzystanie pozwala minimalizować niebezpieczeństwo, jakie niesie ze sobą namowa do stałego powiększania konsumpcji i stanu posiadania. W hierarchii wartości u większości ludzi wciąż dominuje rodzina, przyjaźń, szacunek, praca, miłość itd., stąd można mieć nadzieję, że dla większości społeczeństwa szczęście jest związane z tradycyjnymi wartościami, a nie sprowadza się tylko i wyłącznie do posiadania coraz większej liczby przedmiotów materialnych. Niemniej jednak do szczęścia w świecie konsumpcji niezbędne jest posiadanie pewnej liczby dóbr.

Konsumenci poprzez odpowiednią edukację i położenie silnego nacisku na przestrzeganie kodeksów etycznych dotyczących sposobów uzyskiwania surowców potrzebnych do produkcji, respektowania kodeksów pracy, mogą oddziaływać na producentów. Wpajając społeczeństwu przestrzeganie norm etycznych oraz wykorzystując reklamę społeczną,

31 J. Rachocka, Dekonsumpcja, domocentryzm, ekologizacja życia - nowe tendencje konsumenckie w rozwiniętych gospodarkach rynkowych, [w:] Problemy globalizacji gospodarki, red. T. Bernat, Szczecin 2003, s. 189.

32 J. Rachocka, Dekonsumpcja, domocentryzm, ekologizacja życia..., dz. cyt., s. 190-191.

33 J. Rachocka, Dekonsumpcja, domocentryzm, ekologizacja życia..., dz. cyt., s. 192. 
nastawioną na promocję idei, wartości i postaw prospołecznych, jesteśmy w stanie wpływać na konsumentów, czyniąc ich bardziej refleksyjnymi, racjonalnymi i odpowiedzialnymi ${ }^{34}$. Rozwiązaniem jest rozwijanie idei wolontariatu i solidarności z osobami pokrzywdzonymi, powstawanie stowarzyszeń, grup wsparcia, wspólnot religijnych w ramach Kościołów lub poza nimi. Szczęścia społeczeństwu nowego kapitalizmu nie da hedonistyczne zaspokajanie własnych pragnień przez konsumpcję, ponieważ konsument nigdy nie czuje się w pełni zaspokojony w swoich pragnieniach, a co za tym idzie - konsumenci nie mogą osiągnąć pełnego szczęścia.

Sennett uważa za niezbędne podjęcie szeroko zakrojonej i wytrwałej działalności edukacyjnej, szczególnie wśród młodego pokolenia, które odpowiednio przygotowane nie podda się tak łatwo lansowanemu przez media modelowi szczęścia, a z drugiej strony wprowadzi do niego konieczne zmiany, tak aby człowiek nie popadał zbyt łatwo w nałóg i uzależnienie od konsumowania.

\section{Bibliografia}

Baudrillard J., Społeczeństwo konsumpcyjne. Jego mity i struktury, tłum. S. Królak, Warszawa 2006.

Bauman Z., Konsumowanie życia, tłum. M. Wyrwas-Wiśniewska, Kraków 2009.

Bauman Z., Praca, konsumpcjonizm i nowi ubodzy, tłum. S. Obirek, Kraków 2006.

Morreale S., Spitzberg B., Barge J., Komunikacja między ludźmi. Motywacja, wiedza i umiejętności, tłum. P. Izdebski, A. Jaworska, D. Kobylińska, Warszawa 2007.

Mysona Byrska J., Język w społeczeństwie konsumpcyjnym. Kilka uwag o zmianach, [w:] Ję$z y k$ - podmiot - rzeczywistość. Szkice na temat języka i mowy oraz ich roli $w \dot{z} y c i u$ indywidualnym i zbiorowym, red. M. Żardecka-Nowak, J. Skrzypek-Faluszczak, Rzeszów 2015, s. 169-180.

Mysona Byrska J., Nove hodnoty v magickom svete konzumpcie, [w:] Fyzika a etika VIII. Veda ako kulturny fenomen, red. I. Mihalikova, Nitra 2013, s. 283-291. 
Rachocka J., Dekonsumpcja, domocentryzm, ekologizacja życia - nowe tendencje konsumenckie $w$ rozwiniętych gospodarkach rynkowych, [w:] Problemy globalizacji gospodarki, red. T. Bernat, Szczecin 2003, s. 185-192.

Ritzer G., Magiczny świat konsumpcji, tłum. L. Stawowy, Warszawa 2012.

Sandel M., Czego nie można kupić za pieniądze. Moralne granice rynku, tłum. A. Chromik, T. Sikora, Warszawa 2013.

Saint-Exupéry A. de, Mały Książę, tłum. J. Szwykowski, Warszawa 1985.

Sennett R., Kultura nowego kapitalizmu, tłum. G. Brzozowski, K. Osłowski, Warszawa 2010.

Sennett R., Korozja charakteru. Osobiste konsekwencje pracy w nowym kapitalizmie, tłum. J. Dzierzgowski, Ł. Mikołajewski, Warszawa 2006.

Sennett R., Razem. Rytuały, zalety i zasady wspótpracy, tłum. J. Dzierzgowski, Warszawa 2013.

Weber M., Etyka protestancka a duch kapitalizmu, tłum. B. Baran, P. Miziński, Warszawa 2010. 